\title{
Numerical simulation on Bay of Bengal's response to cyclones using the Princeton ocean model
}

\author{
Yashvant Das ${ }^{1 *}$, Uma Charan Mohanty ${ }^{2,3}$, Indu Jain ${ }^{2}$
}

${ }^{1}$ Research and Modeling Division

(AIR Worldwide India Private Limited Hyderabad-500081, India)

${ }^{2} \mathrm{CAS}$, Indian Institute of Technology

(Hauz Khas, New Delhi-110016, India)

${ }^{3}$ EOCS, Indian Institute of Technology

(Bhubaneshwar-751013, India)

*Corresponding author: yashvantdas@rediffmail.com

\section{Abstract}

This study used the Princeton ocean model (POM) which includes second-order turbulent closure scheme to investigate the fluid dynamics of the Bay of Bengal (BoB) in the upper ocean's response to a cyclone. The model uses an orthogonal curvilinear grid and 26 sigma levels in conformity with realistic bottom topography. The model is forced with wind and heat plus salinity fluxes as surface forcing to simulate the BoB's response during a cyclone. In order to provide the realistic cyclonic vortex the model as input, the synthetic cyclonic vortex is generated and superimposed on the QSCAT/NCEP blended ocean wind fields. Analyses of results show significant sea surface temperature (SST) cooling on both sides of the storm track. This cooling could be attributed to the strong cyclonic winds, surface divergence and upwelling. However, less commonly observed features such as a leftward bias in SST cooling due to the relatively slower motion of TC and southward moving coastal boundary currents are also reported in this study. Model SST is compared with the observed Tropical Rainfall Measuring Mission (TRMM) Microwave Imager (TMI) filled up SST for the evaluation of the model's performance. Moreover, not only sea surface cooling but subsurface warming due to intense downwelling and coastal jet parallel to the coast were also observed in the model's simulation. The mixed layer depth (MLD) variation is revealed by the model. MLD deepening due to the convergence of near surface flow at the periphery of the cyclone is observed; however, beneath the cyclone centre, in the direction of the track the upsloping of isotherms due to the surface divergence and upwelling causes the shoaling of the MLD. Modeled surface currents are compared with 5-day interval OSCAR (Ocean Surface Current Analyses Real time) surface currents, which are not very coherent, though some of the important features like higher values of boundary layer currents are captured. However, strong near surface, asymmetrical responses such as divergent currents in the open oceanic region are reflected by the model but when the cyclone approaches the coast the current patterns do not show the right bias due to interaction with the coast.

Descriptors: Bay of Bengal (BoB), Tropical cyclone (TC), Synthetic vortex, Sea surface temperature (SST) cooling, Divergent current, Mixed layer depth (MLD).

Submitted on: 23/08/2015

Approved on: 03/02/2016

http://dx.doi.org/10.1590/S1679-87592017111206502

\section{RESUMO}

Este estudo utilizou o modelo oceânico de Princeton (MOP), que inclui o esquema fechamento turbulento de segunda ordem, para investigar a dinâmica de fluidos da Baía de Bengala (BB), como resposta do oceano superficial a um ciclone tropical (CT). O modelo utiliza uma grade curvolinear ortogonal e 26 níveis-sigma, em conformidade com a topografia realística do fundo. O modelo foi forçado pelo vento, calor e salinidade superficial, com a finalidade de simular a resposta da BB durante um evento de ciclone. A fim de proporcionar um vórtice ciclônico realista como entrada para o modelo, um vórtice ciclônico sintético foi gerado e sobreposto aos campos de ventos oceânicos misturados QSCAT / NCEP. Os resultados obtidos mostraram resfriamento significativo da temperatura superficial do mar(TSM), em ambos os lados do rastro da tempestade. Esse resfriamento pode ser atribuído aos fortes ventos ciclônicos, à divergência de superfície e também à ressurgência. No entanto, no presente estudo, foi também observada uma característica menos comum, que é o viés para a esquerda no resfriamento da TSM devido a movimentação mais lenta do CT e deslocamento para o sul das correntes de contorno costeiras. Para a avaliação do desempenho do modelo SST, este foi comparado com a "Tropical Rainfall Measuring Mission (TRMM) Microwave Imager (TMI)" observada e que ocupou a SST. Além disso, não só o resfriamento da superficie do mar, mas também o aquecimento da subsuperficie, devido à subsidência intensa e ao jato costeiro paralelo à costa, foi observado pela modelagem. Igualmente, a variação da profundidade da camada mista (PCM) foi revelada pelo modelo. Ocorreu um aprofundamento da Camada Mista, devido à convergência do fluxo próximo da superfície na periferia do ciclone; no entanto, sob o centro do ciclone, ao longo da direcção da subida das isotermas, causada pela divergência de superfície e pela ressurgência, ocorre o empolamento da PCM. Correntes de superfície modeladas são comparadas com as correntes superficiais de 5 dias de intervalo, chamadas de OSCAR (Análises de Correntes Superficiais em Tempo Real), que embora não sendo de grande coerência, permitem que algumas características importantes, tais como valores elevados de correntes da camada limite, sejam capturados. No entanto, perto da superfície, o modelo reflete uma forte resposta assimétrica, tal como a presença de correntes divergentes na região oceânica; porém, quando o ciclone se aproxima da costa os padrões atuais não mostram o viés de direita, devido à interação costeira.

Descritores: Baía de Bengala (BB), Ciclone Tropical (CT), vórtice ciclônico, Resfriamento da temperatura superficial do mar (TSM), corrente divergente, Profundidade da Camada Mista (PCM). 


\section{INTRODUCTION}

Tropical cyclones (TCs) represent intense cases of air-sea interaction processes, where warm surface ocean waters provide energy through surface heat fluxes (EMANUEL, 1986). Latent heat release due to the condensation of water vapor ultimately comes from the ocean (JACOB; SHAY, 2003), which helps in developing strong winds and produces intense mixing and divergent flows in the upper layers of the ocean. Strong TC winds help in the redistribution of ocean waters through vertical mixing (entrainment and upwelling from the depths below) which lead to sea surface temperature (SST) cooling and a corresponding reduction in surface heat fluxes (MAEDA, 1964; GENTRY, 1970; JACOB; SHAY, 2003). The SST plays a crucial role in the genesis and intensification process of the TCs (BENDER et al., 1993; RAO et al., 2007; VISSA et al., 2013). Stronger TC winds induce a deepening of the mixed layer and result in the cooling of the sea surface by several degrees after their passage, which acts as a negative feedback mechanism for TC intensification (PRICE, 1981; BENDER et al., 1993; SHAY; VINCENT et al., 2012a, b, c; VISSA et al., 2013). MOREY et al. (2006) have also suggested that warm SSTs favor the development of tropical cyclones by providing the energy necessary for deep atmospheric convection. Estimates from observations and model simulations reveal that cooling induced by vertical mixing in the oceanic mixed layer heat budget ranges from 70-99 \% (BENDER et al., 1993; JACOB et al., 2000). Decreases in SST may range from $3.5^{\circ}$ to $6^{\circ} \mathrm{C}$ depending on the storm's intensity, forward speed, spatial extent and the oceanic mixed layer's thickness (LEIPPER, 1967; WRIGHT, 1969; PRICE, 1981; STRAMMA et al., 1986; NELSON, 1998; SHAY et al., 1992; WENTZ et al., 2000; SADHURAM, 2004). The heat fluxes to the atmosphere account for less than $20 \%$ of the total SST decrease (ELSBERRY et al., 1976; PRICE, 1981). The thermal response of the ocean due to cyclones has been well investigated through observation and modeling studies in different oceanic basins which have indicated decreases in SST (EMANUEL, 1988; SAUNDERS; HARRIS, 1997; ZEDLER, 2009; NEETU et al., 2012; VINCENT et al., 2012a, b, c).

The upper ocean's response due to the passage of TCs in the North Indian Ocean has been well documented
(SEETARAMAYYA; MASTER, 1984; BEHERA et al., 1998; CHINTHALU et al., 2001; SUBRAHMANYAM et al., 2005; DEO et al., 2012; WANG et al., 2012 a, b; DAS et al., 2014). KARA et al. (2000, 2003a, b) in their model simulation reported an SST drop of $0.5^{\circ} \mathrm{C}$ to $0.8^{\circ} \mathrm{C}$ in the BoB during the passage of TCs. SUBRAHMANYAM et al. (2005); SENGUPTA et al. (2008) also found an SST cooling of $\sim 0.5-1.0^{\circ} \mathrm{C}$ due to a TC over the BoB. RAO (1987, 2000); SEETARAMAYYA et al. (2001); VINAYCHANDRAN et al. (2002) have also evidenced a considerable drop in SST in the BoB due to the passage of TCs.

Variations in mixed layer depth play a significant role in determining the SST response to a TC, which in turn affects surface fluxes (MAO et al., 2000). Upwelling and entrainment of cold subsurface waters into the mixed layer is the widely accepted mechanism of mixed layer (and SST) cooling resulting from hurricanes (PRICE, 1981). SHAY (1994) studied the thermal response and the momentum response within the near-inertial dynamics to the TCs in the upper ocean. DARE; MCBRIDE's (2011) studies reported that the maximum sea surface cooling generally occurred a day after the cyclone's passage. Mechanical energy injected into the ocean by cyclonic wind causes enhanced vertical mixing, a deepening of the mixed layer and a warming of the subsurface layers of the ocean to a depth of at least $500 \mathrm{~m}$ (JULLIEN et al., 2012).

The inherent asymmetry in the coupling between the wind stress and wind-driven mixed layer currents during a cyclone shows the right-hand bias in the current amplitude as an oceanic response to a storm (PRICE, 1981). The mixed layer current structure produces a unique convergence and divergence pattern in the wake of the storm. The high velocity current shear produces a mixing of the cooler thermocline water into the mixed layer, increasing the mixed layer's depth and cooling the sea surface (JACOB et al., 2000; D'ASARO, 2003). Ocean sensors recorded the first velocity structure measurements in the Gulf of Mexico during the passage of Hurricane Eloise (WHITHEE; JOHNSON, 1988) as the ocean's response to a storm. DICKEY et al. (1998) used Bermuda testbed mooring data and investigated the several aspects of upper ocean response to Hurricane Felix (1995). Their findings reveal a significant decrease in SST, strong inertial motion, strong vertical turbulent mixing and heat exchange, and cooling of the upper mixed layer that persisted for several days. ZEDLER et al. (2002) undertook the measurement of horizontal currents 
and temperatures using the multivariable moored system (MVMS) at the Bermuda testbed mooring site during Hurricane Felix (1995). Their data analysis indicates an increase in kinetic energy, mixed layer deepening, and significant vertical redistribution of heat, with cooling of the upper $30 \mathrm{~m}$ and warming at depths of 30 70m. CHINTHALU et al. (2001) analyzed the currents and various air-sea parameters from moored buoy data (collected $3 \mathrm{~m}$ below the surface) deployed at $13^{\circ} \mathrm{N}, 87^{\circ} \mathrm{E}$ in the BoB by the National Institute of Ocean Technology (NIOT) during the passage of TCs and reported SST cooling and opposite trends in currents and winds at the buoy's location. The work of PREMKUMAR et al. (2000) has documented that the ocean's response to a TC can be vital by monitoring the surface weather parameters and the upper ocean current and thermal structure from moored buoys. SUBRAHMANYAM et al. (2005) have documented that the coupling of the surface wind stress to surface current produces a divergent pattern of currents during a storm.

The BoB is one of the largest marginal seas of the Indian ocean, encompassing a surface area of $2.2 \times 10^{6}$ $\mathrm{km}^{2}$ (Figure 1). Because of its semi-enclosed nature (surrounded by land on 3 sides), the BoB is subject to high spatial and temporal variability arising from external forcing factors. TCs that routinely affect the region are one of the significant sources of the BoB's variability. The BoB's thermal structure and circulation are thus connected to the surface wind forcing as is evident through both observational (RAO, 1987; SHETYE et al., 1996; CHINTHALU et al., 2001) and modeling studies (LISAN et al., 1991; POTEMRA et al., 1991; KARA et al., 2000, 2003a, b). Modeling studies on aspects of air-sea interaction processes during suppression, transition and active convective episodes and the observational studies of nearsurface variations and surface fluxes have been extensively investigated in the BoB (BHAT, 2002; MOHANTY et al., 2003; DAS; MOHANTY, 2014). The BoB's intraseasonal thermocline variability (GIRISHKUMAR et al., 2013) including aspects of the dynamic and thermodynamic characteristics of the northern Indian Ocean have been investigated in earlier studies (MCCREARY et al., 1993). However, there are fewer modeling studies on the BoB's response to realistic cyclonic winds than on those in the Pacific and Atlantic oceans. Most of the earlier researches on the BoB's response to TCs were based on the in situ investigations in which the temporal coverage was limited. Moreover, in some cases, the BoB's response to idealized cyclonic vortices were investigated. Modeling studies on the BoB's response to super cyclonic storms were not given much attention in earlier studies. Hence, studies on TCs' impact on the upper ocean calls for the close attention of the scientific community for the advanced understanding of the cyclone-ocean interaction processes in different seasons. Moreover, research has revealed that accurate modeling of the ocean's response to a TC has been problematic due to a lack of realistic and quality wind field studies (MOREY et al., 2006). However, the pioneering research of JELESNIANSKI; TAYLOR (1973); HOLLAND (1980); GEORGIOU (1985); CARR; ELSBERRY (1997) and more recently WILLOUGHBY et al. (2006) has presented the techniques for TC wind field modeling. Such models make use of the characteristics of cyclones as an input parameter in generating cyclonic wind fields for driving numerical models.

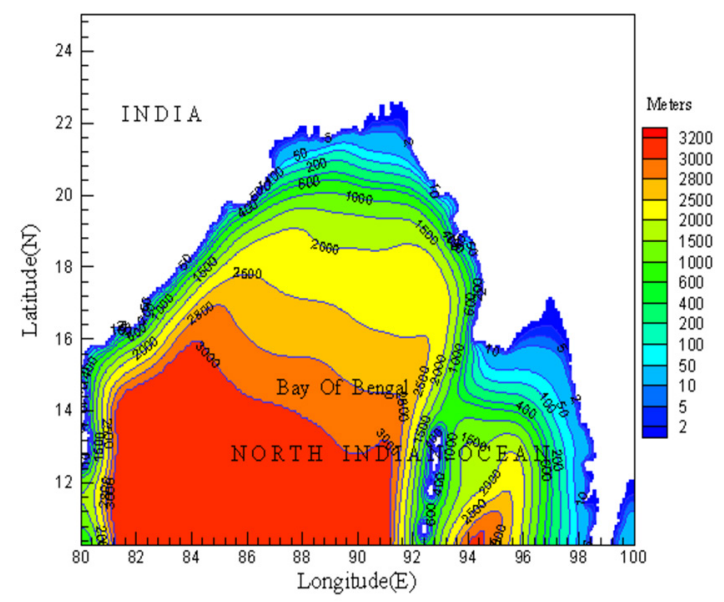

Figure 1. Study domain with bottom topography contours of the Bay of Bengal (North Indian Ocean).

This present study investigates the oceanic response to one of the most severe cyclones ever over the BoB, the Orissa Super Cyclone 1999, using the high-resolution Princeton Ocean Model (POM). The POM was forced with a high-resolution synthetically generated wind field (CARR; ELSBERRY, 1997) embedded with QSCAT/ NCEP (NASA Quick Scatterometer (QSCAT) blended with NCEP re-analysis fields).

\section{MATERIAL AND METHODS}

The Tropical cyclone wind profile model (CARR; ELSBERRY, 1997; CHU et al., 2000) is based on the angular momentum balance to compute the wind vector 
relative to the center of the tropical cyclone to establish a high-resolution surface wind field for the Orissa super cyclone, 1999. The model produces the distinct asymmetrical wind structure of a moving cyclone. The translational velocity of the system causes enhanced wind flows on the right side of the moving cyclone and diminished wind flow on the left side. This asymmetrical wind forcing contributes significantly to the presentation of the impact of the cyclone on ocean thermal structure and current patterns (VENEZIANO, 1998).

The cyclone track characteristics utilized are from JTWC (U.S. Navy Joint Typhoon Warning Centre at Guam). The synthetic asymmetric cyclonic winds are generated by taking into account the cyclone parameters such as size $\left(R_{o}\right)$, distance from the center of the cyclone $(r)$, radius of maximum tangential velocity $\left(R_{\mathrm{m}}\right)$, translational velocity $\left(\mathrm{V}_{t}\right)$ and coriolis parameter $(f)$.

The model cyclone has tangential $\left(v_{c}\right)$ and radial $\left(u_{c}\right)$ wind components varying with the radial distance (r) and which are given as follows:

$$
\begin{gathered}
V_{c}(r)=f_{o} / 2\left[R o(R o / r)^{X}-r\right] \alpha^{4} / 1+\alpha^{4} \\
U_{c}(r)=\tan (\gamma) V_{c}(r)
\end{gathered}
$$

Where, $\gamma=$ inflow angle of the wind, $\alpha=r / R_{m}$ (scaling factor), $x=$ positive constant $<1$ and taken as $x=0.4$. The superimposition of the synthetic wind field with real time QSCAT/NCEP wind data to get the total wind vector (V) is done in a line similar to that of VENEZIANO (1998), as follows.

$$
V=(1-\varepsilon)\left(V_{c}+V_{t}\right)+\varepsilon V_{b g}
$$

Where, $\mathrm{V}_{\mathrm{c}}=$ cyclone wind vector, $\mathrm{V}_{b g}=$ background wind field, $\mathrm{V}_{\mathrm{t}}=$ storm translational velocity, and ' $\varepsilon$ ' is computed by

$$
\varepsilon=c^{4} / 1+c^{4} c=r / 0.9 R o(4)
$$

Where the other symbols have their usual meanings.

It is evident (Or, Evidence is given showing) that satellite-derived winds and high resolution atmospheric reanalysis wind products have difficulty in representing TCs, especially their intensity and track, realistically (SCHENKEL; HART, 2012). The reconstruction (synthetic generation) of TC winds thus becomes necessary to overcome the significant underestimation of TCs' high wind situation (WANG et al., 2012a, b). Hence, tropical cyclone model generated 6-hourly synthetic vortices (26-29 October 1999) were superimposed QSCAT/NCEP blended ocean winds and used in driving the model as realistic cyclonic winds. KLEIN (2008) and LIANG et al. (2012) have used QSCAT/NCEP winds in forcing the numerical ocean model in their studies. QSCAT/NCEP blended ocean wind data from Colorado Research Associates are derived from the spatial blending of high-resolution satellite data (Seawinds instruments of the QuickSCAT satellite-QSCAT) and global weather center re-analysis (NCEP). They have global coverage with high temporal and spatial resolutions (6-hourly and $0.5^{\circ} \times 0.5^{\circ}$ ) (http://dss.ucae.edu/datasets/ ds744.4).

The blended product merges the high wave-number information available from observations with high frequency numerical weather prediction fields (CHIN et al., 1998; MILLIFF et al., 1999). The method uses the spectral properties of the observed winds to synthesize high wave-number winds at times and locations for which no observations exist (GILLE, 2005). NCEP operational forecast model surface wind analyses have been trilinearly interpolated to the QSCAT wind vector cell locations and sample times (MILLIFF et al., 1999). Satellite data are based on Direction Interval Retrieval with Threshold Nudging (DIRTH) algorithm centered on the analysis time. Quality control of this global uniform coverage data is based on CHIN et al., 1998 and MILLIFF et al., 2004. In order to avoid duplication no further correction/comparison is repeated as between NCEP and QSCAT, i.e. (QSCAT/NCEP) datasets. The cubic spline interpolation technique is used to bring the superimposed wind fields to match the resolution of the model. The 6-hourly evolutions of superimposed wind vectors plots from 0600 UTC 26 to 1800 UTC 29 October 1999 are generated and the 24-hour time interval from 26 to 29 October 1999 at 00UTC of each day is shown in Figure 2 (DAS et al., 2016). The reference wind vector (arrow) representing the magnitude of wind velocity is $45 \mathrm{~m} / \mathrm{s}$ for all the plots, though magnitude varies on different days of the storm's passage. The maximum value of superimposed wind during the life stage of the storm was $\sim 71.43 \mathrm{~m} / \mathrm{s}$, that is in accordance with the JTWC reports of $\sim 70 \mathrm{~m} / \mathrm{s}$.

\section{THE OCEAN MODEL}

\section{MODEL CONFIGURATION, FORCING FIELDS}

This study has been conducted using POM numerical simulations of the BoB. The POM was developed at the Geophysical fluid Dynamical Laboratory (GFDL) of Princeton University, USA for the simulation of coastal, regional and global ocean characteristics. The POM is 

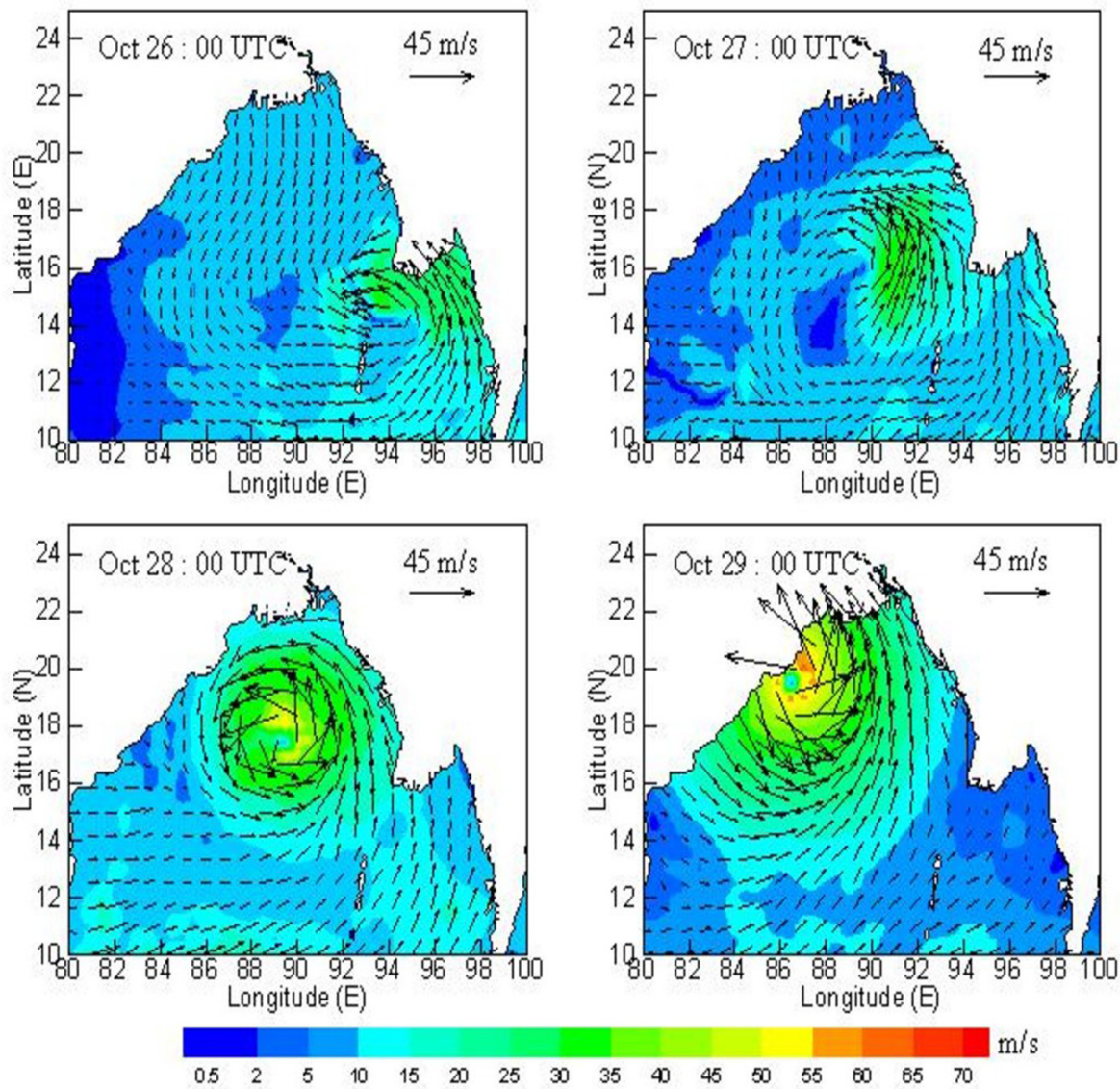

Figure 2. Cyclone wind field model generated surface wind fields superimposed with QSCAT/NCEP over the BOB on October 26-29, 1999, representing the Orissa super cyclone.

a primitive equation ocean model with hydrostatic and Boussenisq approximations on a three-dimensional grid with complete thermodynamics that includes realistic topography and a free surface. It is a general circulation as well as a coastal ocean model that provides a dynamic connection between the general circulation of the deep ocean and the variation of coastal waters (BLUMBERG; MELLOR, 1987). It has a second-order turbulence closure scheme (MELLOR; YAMADA, 1982) to parameterize vertical mixing and SMAGORINSKY (1963) eddy viscosity to parameterize horizontal mixing. The model has the sigma vertical coordinate (terrain-following) system to handle complex topographies and shallow regions and a curvilinear grid to better handle the coastline (BLUMBERG; MELLOR, 1987). The model has the mode splitting time - steps of the barotropic (external) and baroclinic (internal) mode to save computer resources. Details of this model can be found in the POM user's guide (MELLOR, 2004). Previous studies have indicated that the POM could well reproduce oceanic features. POM has been applied in the BoB (MAHAPATRA et al., 2007) and the Arabian Sea (RAO et al., 2010) in the India Ocean to simulate the ocean's response to cyclones. CHU et al. $(2000,2001)$ have applied the POM in the South China Sea (SCS) and captured its oceanic characteristics well. EZER (2000) configured POM in the north-east Atlantic and the Gulf of Mexico. HONG et al. (2012) have implemented the POM in the northwestern Pacific Ocean.

The model used in this study extends from $10.0^{\circ}$ to $22.0^{\circ} \mathrm{N}$ and $80.0^{\circ}$ to $100.0^{\circ} \mathrm{E}$ (Figure 1). The orthogonal curvilinear grid with Arakawa C-grid staggering (HALTINER; WILLIAMS, 1980) with a variable horizontal grid resolution of 4 to $12 \mathrm{~km}$ is configured. The model has $250 \times 250$ horizontal grid points and 26 layers in the vertical dimension (the majority of these layers are located in the upper levels to better depict the cyclone-related mixed layer processes and the upper ocean/surface current system). The model uses the bottom 
topography derived from the Earth Topography and Ocean Bathymetry Database (ETOPO5) at 5-min. resolution from the NGDC (U.S. National Geophysical Data Centre, http://www.ngdc.noaa.gov) database as shown in Figure 1. A bilinear interpolation has been used to obtain depths on computational grids and simultaneously depths are smoothed to remove the spurious along-slope current caused by the topographic variation in a sigma coordinate model (HANEY, 1991).

The two-dimensional external mode uses a short time-step of $12 \mathrm{sec}$. based on the external wave speed, while a three-dimensional internal mode uses a long time-step of $540 \mathrm{sec}$. based on the internal wave speed. The Courant-Fredrick-Levy (CFL) condition has been followed for computational stability. An implicit time integration scheme with splitting mode time steps are used for computational efficiency. The atmospheric forcing includes wind and heat plus salinity flux forcing for the BoB application of POM. Runoff (river discharge) has not been taken into account in this study. No advective or diffusive heat, salt or velocity fluxes occur through closed lateral boundaries, i.e. the modeled ocean bordered by land (CHU et al., 2000). At open boundaries, the numerical grid ends but the fluid flow is unrestricted. When the water flows into the model's domain, temperature and salinity at the open boundary are likewise prescribed from the mean monthly climatology data (LEVITUS; BOYER, 1994; LEVITUS et al., 1994). Radiative boundary conditions are prescribed for momentum and thermal variables at the lateral open boundaries when water flows out of the domain (HANEY, 1971; CHU et al., 1988).

\section{EXPERIMENT DESIGN}

Numerical model experiments are conducted to study the case of the Orissa Super Cyclone 1999. This cyclone was initially formed over the SCS on 23 October at 0200 UTC, and tracked through the Gulf of Thailand and across the Malay Peninsula on 24 October 1999. Further, it continued moving westward at the rate of slow intensification before developing over the Andaman Sea. The Orissa super cyclone first entered the BoB late on 25 October 1999 as a tropical depression $(12.5 \mathrm{~m} / \mathrm{s}$, i.e., $25 \mathrm{knots}, 1 \mathrm{knot}=0.5 \mathrm{~m} / \mathrm{s}$ ) centered at $12.8^{\circ} \mathrm{N}, 98^{\circ} \mathrm{E}$ at 1200 UTC as suggested by wind analyses from JTWC at Guam. By 1200 UTC on 26 October 1999, it slowly translated northwards and intensified into a cyclonic storm $(17.5 \mathrm{~m} / \mathrm{s}, \mathrm{JTWC})$ and lay at $14.8^{\circ} \mathrm{N}, 94^{\circ} \mathrm{E}$ as reported by Indian Daily Weather Reports issued by the IMD (India
Meteorological Department) at New Delhi. Subsequently, the cyclonic storm moved northwestwards and had taken the position $17.5^{\circ} \mathrm{N} 90.6^{\circ} \mathrm{E}$ by 1200 UTC on 27 October 1999. The maximum wind speed was $\sim 32.5 \mathrm{~m} / \mathrm{s}$ as reported by JTWC. Having continued to intensify northwards into a severe cyclonic storm with a core of hurricane winds, it lay at $18.9^{\circ} \mathrm{N}, 88.1^{\circ} \mathrm{E}$ by 1200 UTC on 28 October 1999 (IMD) and the maximum wind speed as analyzed by JTWC was $\sim 50.0 \mathrm{~m} / \mathrm{s}$. The TC then continued moving westward and prior to its landfall on 29 October 1999, positioned at $18.5^{\circ} \mathrm{N}, 88.0^{\circ} \mathrm{E}$ at $1200 \mathrm{UTC}$, it turned into a 'Super Cyclone' from a very severe cyclonic storm and crossed the coast near Paradeep between 0300 UTC and 1200 UTC on 29 October 1999. The Maximum sustained winds as reported by JTWC were $\sim 70.0 \mathrm{~m} / \mathrm{s}$ with minimum central pressure of 912 hpa (KALSI, 2006; IMD). The track of the Orissa super cyclone 1999 (JTWC) is shown in Figure 3. MOHANTY et al. (2004) and KALSI (2006) in their studies have discussed the characteristics of the storm in detail. These characteristics presented an opportunity for conducting a numerical experiment to study the oceanic response of the $\mathrm{BoB}$ to this storm.

The experiment is initially carried out starting with a null initial velocity and three-dimensional temperature and salinity climatological fields (LEVITUS; BOYER, 1994; LEVITUS et al., 1994), forced by monthly mean wind stress (CHIN et al., 1998; MILLIFF et al., 1999), before proceeding to the real time model simulations. Further, the model integration was performed for 3 months 24 days and its final state was taken as the condition of the BoB on October 25, 1999 (The model's year consists of 360 days,

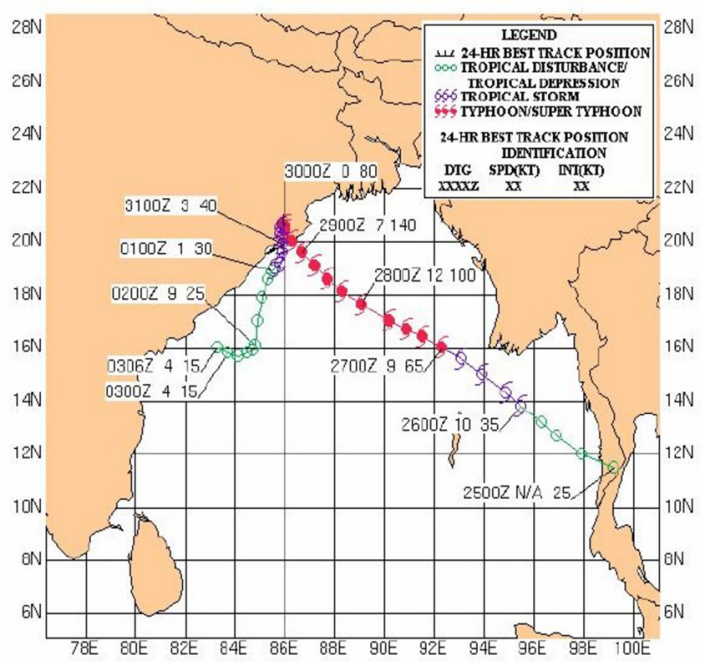

Figure 3. Track of Orissa super cyclone 1999 (JTWC). 
i.e. has 30 days per month, so that day 361 corresponds to 1 January) and considered as the initial condition for the experimental stage. During the experimental stage, the model was integrated for 3 days (0600 UTC 26 to 0600 UTC 29 October 1999), forced with the superimposed 6-hourly winds and the heat plus salinity flux (DA SILVA et al., 1994) fields. Since the average life period of tropical cyclone in the $\mathrm{BoB}$ (NIO) is $\sim 2-3$ days as against the world average of $\sim 6$ days (RIEHL, 1979). That is, cyclones are comparatively short-lived in this area. The model fields are stored at 6 hour-intervals and the instantaneous snap shots at 1800 UTC on 26, 27 and 28 October and 0600 UTC on 29 October 1999 are used for the graphs and the discussion.

The results of the model's simulations of the Orissa super cyclone 1999 on SSTs, the vertical thermal and mixed layer depth, surface and subsurface current structures, as also the BoB's upper ocean response to the cyclone are discussed here.

\section{RESULTS AND DISCUSSION}

\section{SEA SURFACE TEMPERATURE (SST) COOLING}

The SST cooling response due to the passage of the cyclone is a striking phenomenon. Figure 4 shows the comparison of the evolution of SST induced by the cyclone in its different life stages from 26 October to 29 October 1999. The observed SST's are in the left panel of Figure 4 (TRMM/TMI filled up) and the modeled SSTs are shown in the right panel. The cyclone's track during its passage on the various days (25-29 October) are superimposed with the spatial plots (maps). Model simulated SST showed pronounced variations in the temperature fields on the different days of the cyclone's passage. As the cyclone moved northwestwards, the cooler SST, coupled to the cyclone's centre moved along with it. In the early integration when the cyclone was a relatively less intense system (26 and 27 October) as shown in Figure 3, its wind speed was relatively lower and it moved faster $(\sim 4.5-5.0$ $\mathrm{m} / \mathrm{s}$, JTWC) and no obvious SST cooling centre was formed. On 28 October, however, a well marked cooling centre was observed due to the coupling of comparatively higher wind speeds with those of ocean, though the cyclone's movement was faster $(\sim 6.0 \mathrm{~m} / \mathrm{s}$, JTWC; as shown in Figure 3$)$ than on the previous day. The SST's cooling becomes more and more obvious on 29 October due to high wind stress and the relatively slower movement $(\sim 3.5 \mathrm{~m} / \mathrm{s}$, JTWC) of the cyclone and the maximum SST cooling approaches the cyclone's centre on either side (PRICE, 1981; STRAMMA et al., 1986). The SST's cooling during the passage of a cyclone could be attributed to the combined effect of the relatively slower movement of the cyclone and the mixing due to high wind stress (PRICE, 1981; VINCENT et al., 2012a, b, c; WANG et al., 2012a, b). The modeled SST and the TRMM/TMI-derived daily SST during the same period are qualitatively compared. The modeled SST on 28 and 29 October shows greater cooling than the observed SST, thus indicating some discrepancy (Figure 4). Since river discharges have not been considered and the model is forced with the large scale product of precipitation fields (DA SILVA et al., 1994), this may lead to the discrepancy. Moreover, a pronounced rightward bias in SST cooling with respect to the cyclone track on 28 October was observed, because of the dominant wind stress forcing towards the right of the cyclone track (right asymmetry). BEHERA et al. (1998); SUBRAHMANYAM et al. (2005); RAO et al. (2007); MANEESHA et al. (2012); WANG and HAN (2014) have indicated a rightward bias in SST cooling in the BoB during a cyclone. Studies in other oceanic basins, namely those by SHAY et al. (1992) for hurricane Gilbert (1998), WADA (2005) for Typhoon Fex (1998), VENEZIANO (1998) for TC Ernie (1996) and ZEDLER (2009) for Hurricane Felix have also revealed the rightward bias in SST cooling. However, when the slower translating cyclone was approaching the coastline on 29 October, the model depicted SST cooling to the left instead of the right of the cyclone track in contrast to the common belief that the maximum cooling always occurs to the right of the cyclone. This less commonly observed feature during cyclones could be attributed to the southward propagating coastal jet (boundary layer current) which changes the wake of SST cooling to the left side. JAIMES; SHAY (2015) have explained the leftward bias stating that the boundary layer current/coastal jet with eddies can provide vorticity relative to the background flow and potentially modify the hurricane's wake during the forced stage of the response. PRICE (1981) states that the leftward bias in the SST field is due to the small translation speed. Through satellite observations (SADHURAM, 2004) and modeling studies (MAHAPATRA et al., 2007) the leftward bias in SST cooling in the BoB has also been evidenced. The difference in SST relative to that of 25 October (the SST of 25 October is termed pre-storm condition SST), approximating to an SST anomaly due to the cyclone, attained its maximum on 29 October - amounting to $\sim-4.0^{\circ} \mathrm{C}$; however on 28 October, the SST anomaly was of $\sim-3.5^{\circ} \mathrm{C}$ (Figure 5). 

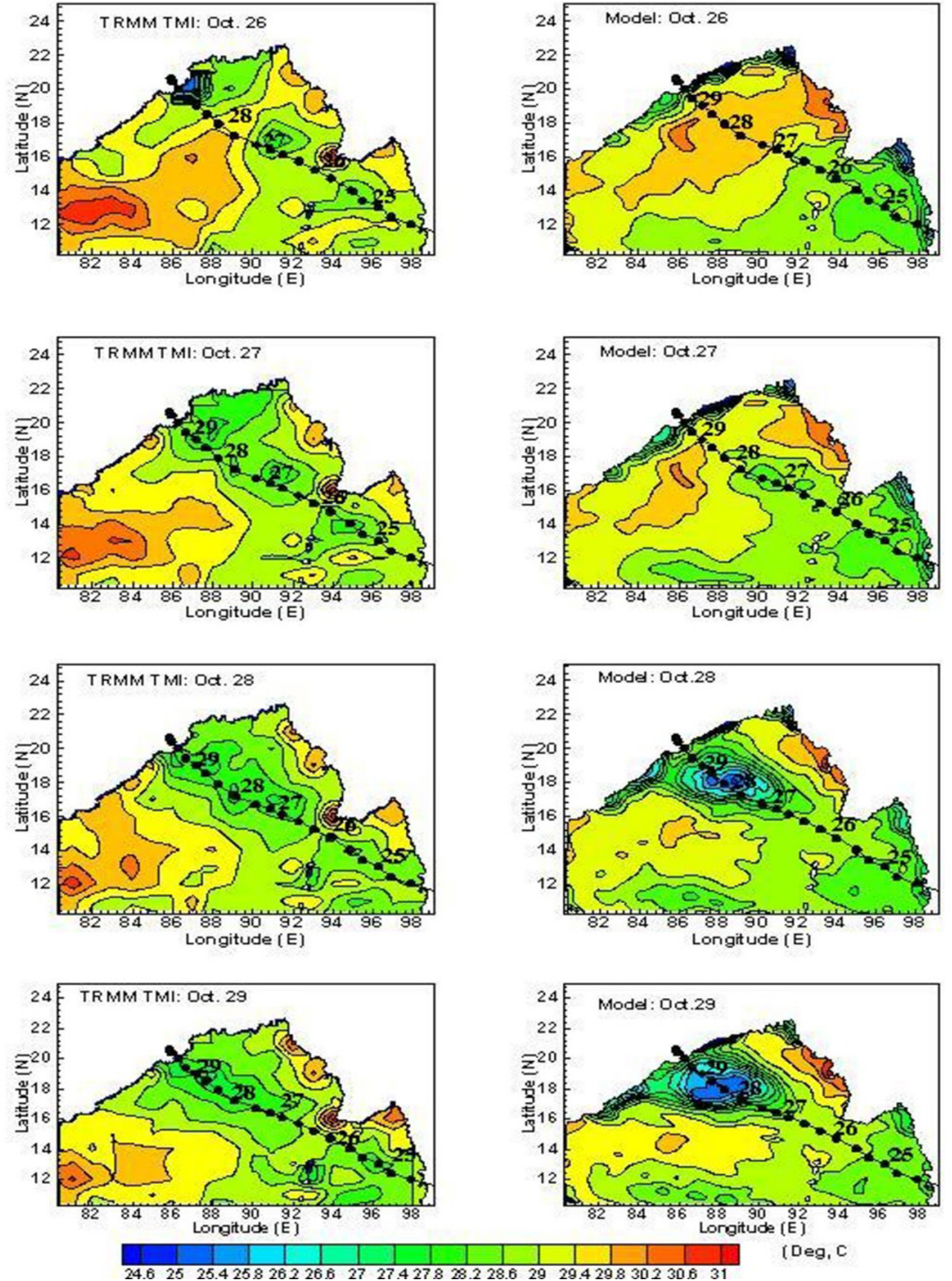

Figure 4. Comparison of the observed (TRMM/TMI) SST (Left panel) fields with modeled SST (Right panel).

VERTICAL THERMAL STRUCTURE AND SUBSURFACE TEMPERATURE ANOMALY, MIXED LAYER DEPTH (MLD) VARIATION AND SURFACE /SUBSURFACE CURRENTS

Three transects in the study area $(\mathrm{BoB})$ have been chosen for the study of the vertical thermal structure, thermal anomaly, MLD variation and subsurface current structures. Vertical thermal structures along the three zonal transects [transect-I $\left(20.5^{\circ} \mathrm{N}\right)$, transect-II $\left(19.3^{\circ} \mathrm{N}\right)$ and transect-III $\left.\left(17.7^{\circ} \mathrm{N}\right)\right]$ are studied.

Along transect-I, as shown in Figure 6, the left, middle and right panels represent the vertical thermal structures during pre-storm condition, storm condition (29 October,
1999 ) and thermal structure anomaly (relative to pre-storm condition), respectively. From Figure 6, it is evident that during the study period the vertical thermal structure showed the pronounced variation in model simulated temperature fields when compared with the initial fields (pre-storm conditions). The isotherms slope up due to the vertical pull of deeper (subsurface, cooler) waters through surface divergence and upwelling under storm conditions. The $27.5^{\circ} \mathrm{C}$ isotherm has upsurged to the surface and the warming zone (pre-storm condition) as represented by the $28.00 \mathrm{C}$ isotherm at the surface at $\sim 89.2^{\circ} \mathrm{E}$ has migrated eastwards, along transect-I. The subsurface cooler waters have come up to the surface on the western side of this transect. The $28.0^{\circ} \mathrm{C}$ isotherm at $\sim 60 \mathrm{~m}$ depth has risen to the surface. Such results have been 

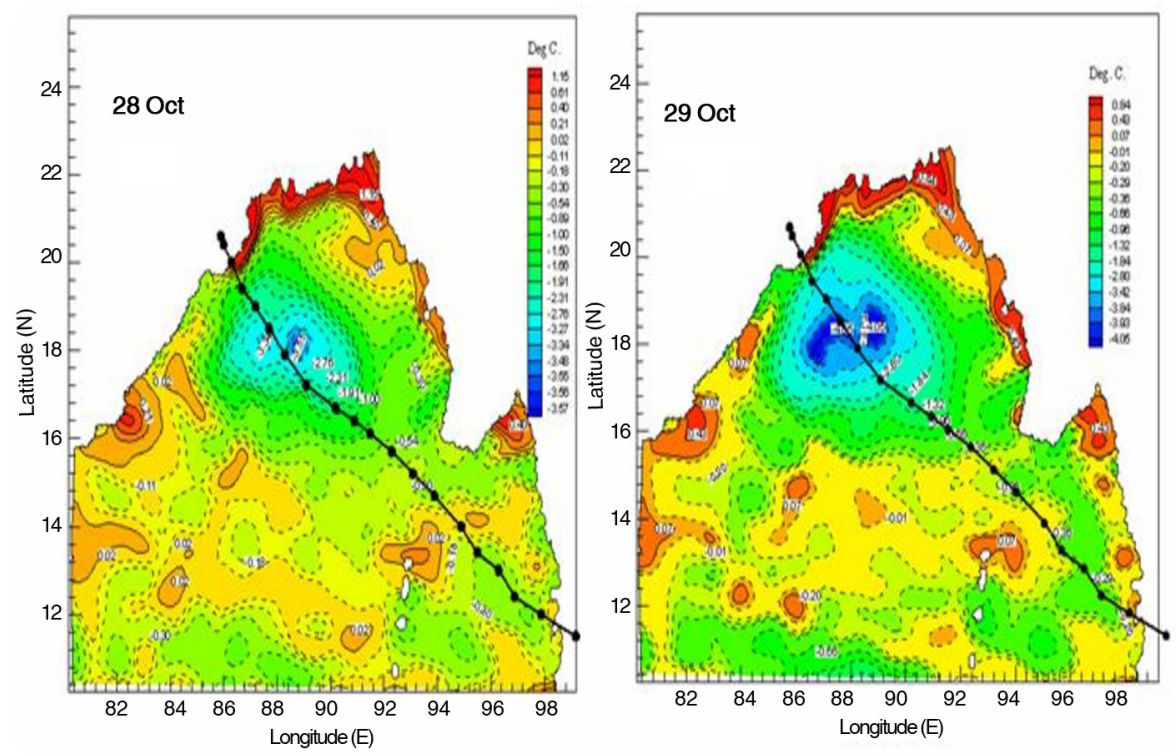

Figure 5. SST anomaly on 28 and 29 October 1999 relative to pre-storm conditions (Contours with dashed lines show SST cooling).

reported in earlier studies by WADA (2002). The upswing of isotherms could be observed up to the depth of more than $150 \mathrm{~m}$. The vertical influence of TCs up to a depth of $>250$ $\mathrm{m}$ has been reported in the BoB by GOPALAKRISHNA et al. (1993). The difference in vertical subsurface thermal structure as between pre-storm and storm conditions, i.e., the subsurface vertical temperature anomaly quantifies the actual cooling in the water column due to the passage of the cyclone. A cooling of about $2.0^{\circ} \mathrm{C}$ (depth $\sim 60 \mathrm{~m}$ subsurface) has occurred beneath the cyclone centre along transect-I, which could be attributed to vertical advection and mixing.

The changes in vertical thermal characteristics during cyclones in comparison to pre-storm conditions along transect-II are also described (Figure not shown). Along this transect, the $25.5^{\circ} \mathrm{C}$ isotherm at $\sim 58 \mathrm{~m}$ depth has risen to the surface, the $29.0^{\circ} \mathrm{C}$ isotherm at $88.8^{\circ} \mathrm{E}$ has migrated eastwards as far as $92.0^{\circ} \mathrm{E}$ and a pronounced cooling of surface waters i.e., a decrease in surface water temperature from $28.0^{\circ} \mathrm{C}$ to $26.5^{\circ} \mathrm{C}$ has occurred as compared to prestorm conditions. The cooling of waters by $\sim-4.5^{\circ} \mathrm{C}$ at $\sim$ $60 \mathrm{~m}$ depth due to upwelling as a negative anomaly and a corresponding warming of $\sim 4.0^{\circ} \mathrm{C}$ due to intense down welling has also been considered a positive anomaly effect away from the storm centre at the depth of $\sim 100$ m. ZEDLER et el. (2002) also indicated the subsurface warming between 40 and $70 \mathrm{~m}$ depth during hurricane Felix. Similarly, along transect III (Figure 7), it is obvious that the warming zone of the pre-storm condition at the surface

\section{Transect I: Lat $205 \mathrm{~N}$}

250 ct 1999

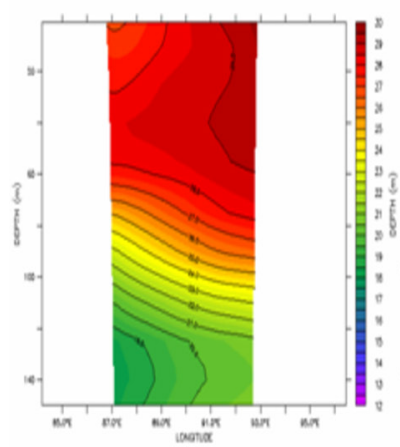

Pre-storm
29 0ct 1999

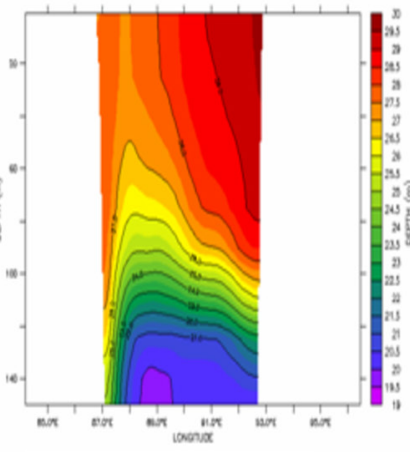

Stornt
29 0ct 1999

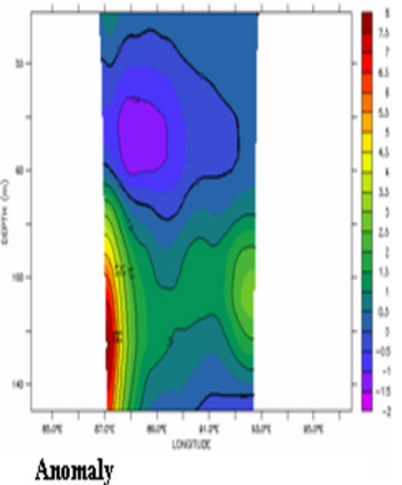

Figure 6. Vertical thermal structure and anomaly along transect I. 
from $86^{\circ} \mathrm{E}$ to $94^{\circ} \mathrm{E}$ represented by the $29.0^{\circ} \mathrm{C}$ isotherm is eroded by relatively cooler isotherms of $28.0^{\circ} \mathrm{C}$ from $86^{\circ}$ to $91^{\circ} \mathrm{E}$ under storm conditions. This could be attributed to the upward movement of subsurface cooler waters during the storm along this transect. Subsurface cooling of about $-3.5^{\circ} \mathrm{C}(\sim 60 \mathrm{~m})$ has been observed and the compensating warming $\left(\sim 1.5^{\circ} \mathrm{C}\right)$ due to downwelling waters away from the centre of the storm at a depth ranging from $\sim 60$ to 80 $\mathrm{m}$ is also observed. Though warming could be observed on either side of the storm away from the storm's core region along this transect, more subsurface warming was reflected to the left than to the right side. RAO et al. (2010) in their simulation studies of the Arabian Sea (North Indian Ocean) also suggest the subsurface warming and surface cooling during the passage of a cyclone and confirmed their findings through observed data. The features of these vertical thermal structures clearly depict the upper ocean's response to the cyclone.

\section{MIXED LAYER DEPTH (MLD)}

The mixed layer depth was found by searching for the depth at which the temperature was at least $0.50 \mathrm{C}$ lower than that at the surface, following a line of thought similar to LEVITUS's (1982). EZER (2000) has also used the temperature criterion in determining MLD in his study. A temperature gradient based scheme was used by ALI and SHARMA (1994) for estimating the MLD of the equatorial Indian Ocean. However, LEVITUS (1982) used this definition as well as a density based one, but in this study the temperature criterion has been followed.

The depth versus longitude plots of the model-derived mixed layer depth (solid black line over the colour filled isotherms) during the study period in the study area along the three zonal transects (I, II and III) are presented. The result indicates that as a cyclone moves northwestwards, considerable variations in MLD occur when compared with the pre-storm conditions - as shown in Figures 8 and 9, for transects I and III respectively (The Figure for transect II is not shown). The deepening of the MLD (relative to the pre-storm condition of 28 and 29 October) has occurred to the left of the storm track - which could be attributed to the convergence of the near surface flow at the periphery of a cyclone, followed by the entrainment and mixing and hence deepening of the MLD (Figure 8).

However, beneath the cyclone's centre, in the direction of the track, the upsloping of isotherms due to the surface divergence and upwelling, causes the shoaling of the MLD (with a reduction of its thickness) (Figure not shown). Along transect-I, under pre-storm conditions the MLD varied from $\sim 5$ to $65 \mathrm{~m}$ thick. On 28 and 29 October the MLD values ranged from $\sim 12$ to $72 \mathrm{~m}$ and $\sim 18$ to 100 $\mathrm{m}$, respectively, i.e., within a 24-hour interval the MLD had deepened by $\sim 30 \mathrm{~m}$ overall along this transect. But as a cyclone moved northwestwards the MLD's thickness has diminished. It may be observed that under pre-storm conditions the maximum value for the thickness of MLD $(\sim 65 \mathrm{~m})$ was extended from about $91.0^{\circ} \mathrm{E}$. On the other hand, during the passage of a cyclone the maximum value of the thickness of MLD $(\sim 32 \mathrm{~m})$ has receded to as far as $88.0^{\circ}$ E. ZEDLER et al. (2002) reported a maximum MLD of $\sim 50 \mathrm{~m}$ during the passage of Hurricane Felix in their observational and simulation studies using different parameterization schemes in the Bermuda testbed mooring site. This shoaling of the MLD could be due to upwelling processes. In the southwestern part of the BoB, that is,

\section{Transect III: Lat 17.7 N}

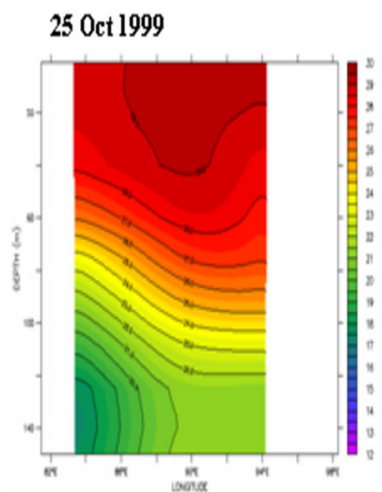

Pre-storm
29 0ct 1999

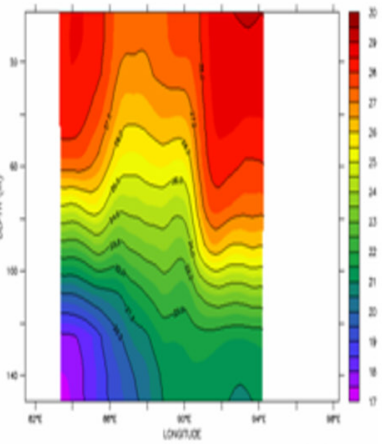

Storm
29 0ct 1999

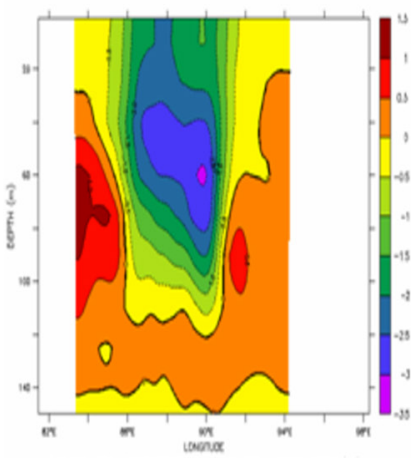

Aromaly

Figure 7. Vertical thermal structure and anomaly along transect III. 


\section{TransectI: Lat $205 \mathrm{~N}$}

250 ct 1999

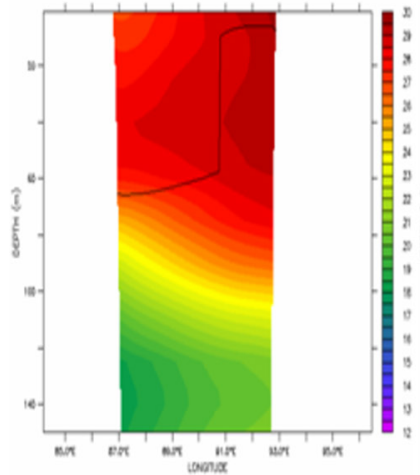

Pre-storm
28 0ct 1999

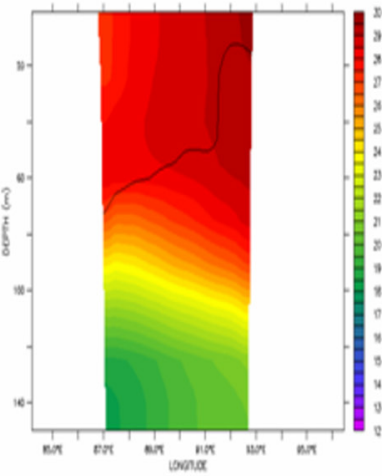

Storm
29 0ct 1999

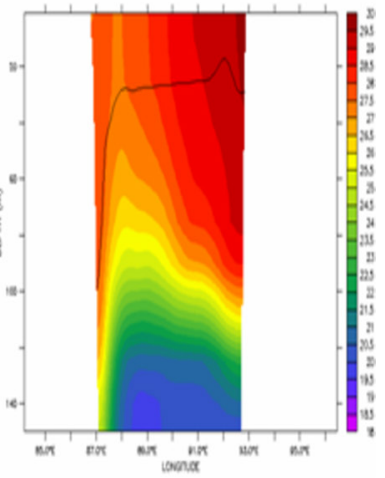

Storm

Figure 8. Mixed layer depth variation along transect I.

\section{Transect III: Lat 17.7 N}

$250 \mathrm{ct} 1999$

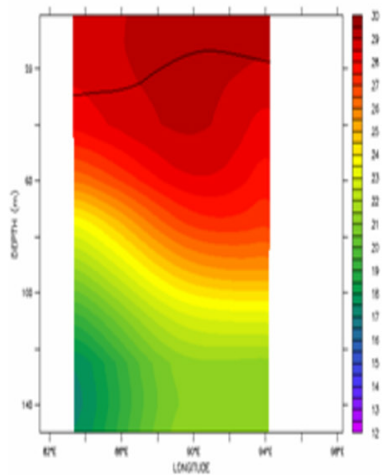

Pre-storm
28 0ct 1999

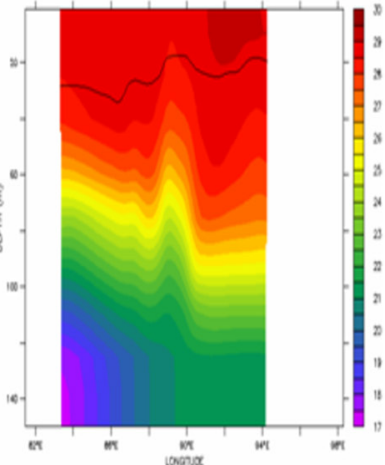

Storm
29 0ct 1999

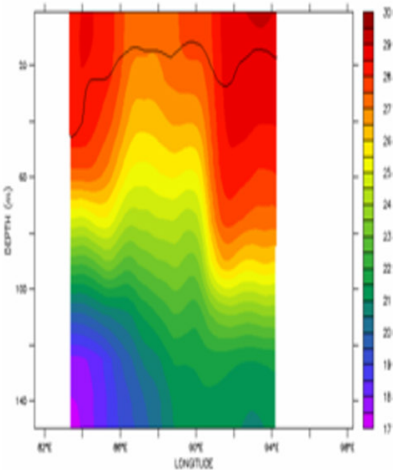

Storm

Figure 9. Mixed layer depth variation along transect III.

along transects II and III, it is to be observed that MLD is shallower than on transect I. SUBRAHMANYAM et al. (2005) have also indicated a shallower MLD during the passage of a cyclone over the BoB. They attributed the moisture convergence to the shallower MLD, which inhibits further MLD development (deepening) during cyclones. These results suggest that cyclone-induced divergence (at a cyclone's centre) and convergence away from the centre are responsible for the variation in the MLD.

\section{SURFACE AND SUBSURFACE CURRENTS}

Modeled surface currents during the passage of a cyclone over BoB from 26 to 29 October are shown in Figure 10. The average of 4 days from 26 to 29 October is also shown compared with 5-day interval OSCAR (Ocean Surface Current
Analyses - Real time) surface currents. These data are available at 5-day intervals with $1 / 3$ degree spatial resolution and hence the surface current centred at 27 October 1999 is used to compare with the daily simulations as well with the 4-day (26-29 October) average of daily simulations. The magnitude of the surface currents is represented with $200 \mathrm{~cm} / \mathrm{s}(2.0 \mathrm{~m} / \mathrm{s})$ reference arrow vectors for all the plots. Surface current velocity varies with each day of the cyclone's passage. From the Figure, it is evident that modeled surface currents show the outflow from the cyclone's centre which produces very strong divergence in the upper layer currents, more conspicuous on 28 and 29 October.

The maximum magnitude of the flow is located to the right of the storm track in the open oceanic region of the $\mathrm{BoB}$ as indicated by the color shades of the current vector's magnitude (Figure 10). This right asymmetry could be explained by the direction of the rotation on 

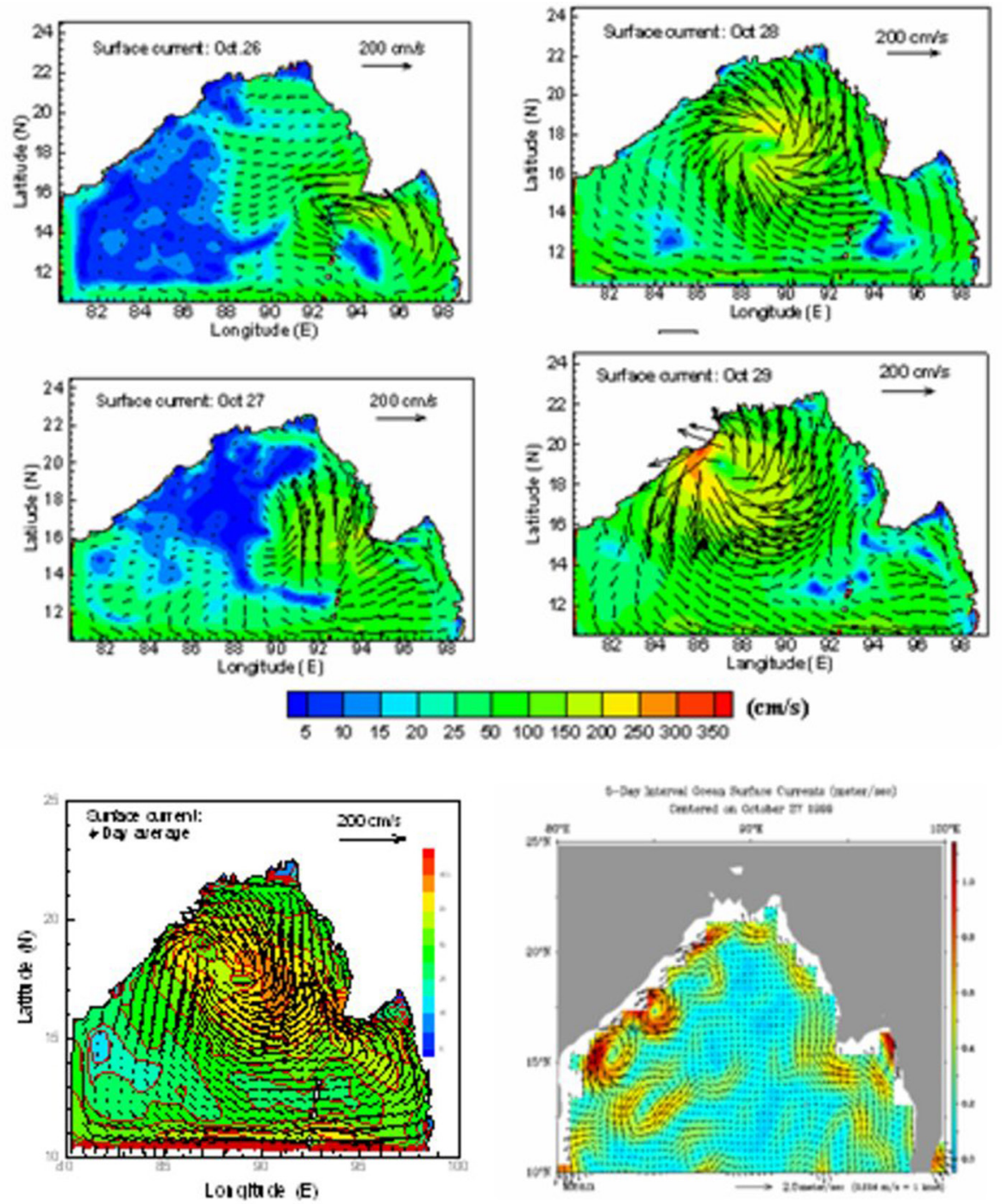

Figure 10. Modeled surface currents comparison with OSCAR surface currents.

either side of the track with respect to time. The inertial forces turn the ocean currents in the same (opposite) direction as the wind stress on the right (or left) side of the track (CHU et al., 2000). But when the cyclone approaches the coast the current patterns do not show the right bias due to the coastal interaction. A strong southerly coastal jet parallel to the coast (near $19.3^{\circ}$ $\mathrm{N}$ at Gopalpur, Orissa, on the east coast of the Indian subcontinent) with a magnitude of surface current $\sim 350$ $\mathrm{cm} / \mathrm{s}$ (maximum) is depicted by the model. However, modeled surface currents are not closely coherent with OSCAR surface currents, though some of the important features like higher values of boundary layer currents are captured. This is clearly seen from the cross-section of the $\mathrm{v}$ - component of current fields taken along transect-II on 29 October (Figure 11). The magnitude of current varying from $250-350 \mathrm{~cm} / \mathrm{s}$ in the zonal cross-sectional plots is also reflected. The model produces very intense vertical shear across the base of the mixed layer with $50 \mathrm{~cm} / \mathrm{s}$ northward flow in the mixed layer and $50 \mathrm{~cm} / \mathrm{s}$ southward flow on the thermocline on 28 Oct (Figure 11). The same cross-sectional features are also observed on transect-I but of lower magnitude $(\sim 200 \mathrm{~cm} / \mathrm{s})$ of the current's v-components. Along transect-I, on 28 October the vertical shearing zone is turning to $180^{\circ}$ indicating the phase reversal with northward flow in the mixed layer, which was produced by wind stress. However, the southward component of currents on the thermocline was produced by the pressure gradient effect (VENEZIANO, 1998). On 29 October, the strong northward v-component 
of currents with magnitude of $\sim 200 \mathrm{~cm} / \mathrm{s}$ and southward $\mathrm{v}$-component of currents with magnitude of $\sim 150 \mathrm{~cm} / \mathrm{s}$ were simulated by the model. Based on the cyclone's forward speed, the maximum surface current estimated by GREATBATCH (1983) was $270 \mathrm{~cm} / \mathrm{s}$. The POMmodeled maximum surface current magnitude was 200 $\mathrm{cm} / \mathrm{s}$ for storm Ernie (1996) as indicated by CHU et al. (2000) for SCS. Similarly, the maximum magnitude of simulated surface currents for hurricane Rita (2005) was $\sim 280 \mathrm{~cm} / \mathrm{s}$ and for hurricane Katrina (2005) $350 \mathrm{~cm} / \mathrm{s}$ in the region of the Gulf of Mexico (OEY et al., 2005). The model simulated surface currents during a cyclone over the $\mathrm{BoB}$ in the present study are comparable with those results.

Results show that strong current shear across the base of the oceanic mixed layer induces a significant amount of mixing and SST cooling occurs due to the strong cyclonic wind (stress). Moreover, when the initial MLD (i.e., of pre-storm conditions) is shallow, the temperature cooling is more pronounced.

\section{POM MODEL VERIFICATION}

TRMM / TMI filled up sea surface temperature (SST) is used to verify the POM-modeled SST fields. The POM simulated SST fields show some agreement qualitatively with observations along the path on the various days of the cyclone's passage. However, the SST cooling observed, especially on 28 and 29 October does not agree with the modeled SST, there being a stronger response in the model. This discrepancy could be due to the precipitation forcing described by DA SILVA et al. (1994), which is a large scale product and the non-inclusion of river discharge in the model. For a quantitative evaluation of the model's performance the root mean square (RMS) error between the simulated SST and the TRMM/ TMI filled up SST is computed (Figure 12). The RMS error from 26 to 29 October ranged between 0.86 and $1.07^{\circ} \mathrm{C}$. RMS errors of 0.7 to $1.3^{\circ} \mathrm{C}$ were evaluated by CHU et al. (2000), who used the Multichannel Sea Surface Temperature (MCSST) data obtained from the polar orbiting Defense Meteorological Satellite Program (DMSP) to verify

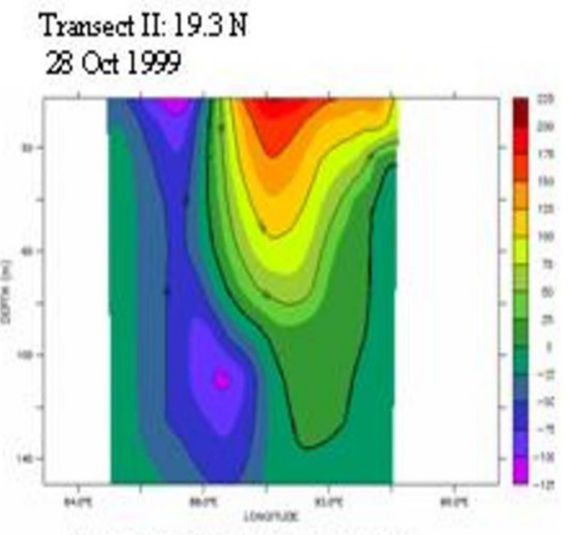

Zanal cross-section of simulated $x$

\section{Tramsect I: $205 \mathrm{~N}$ 28 oct 1999}

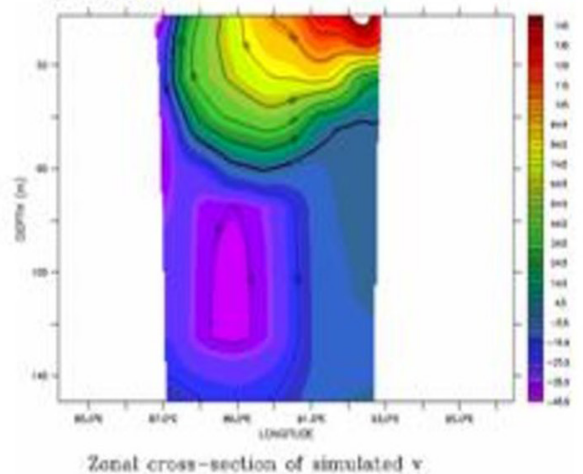

\section{$290 \mathrm{ct} 1999$}

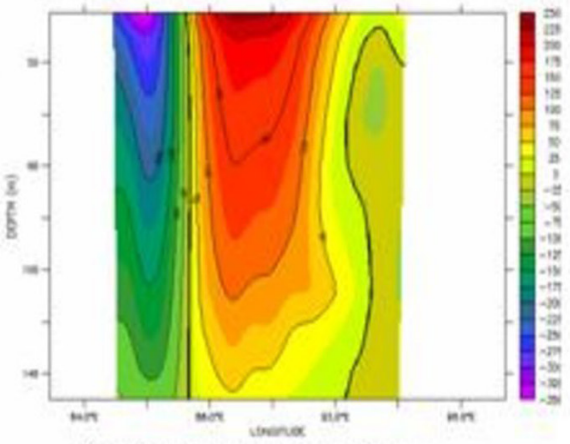

Zonal cross-sectioe of simulated $\mathrm{v}$

290 oct 1999

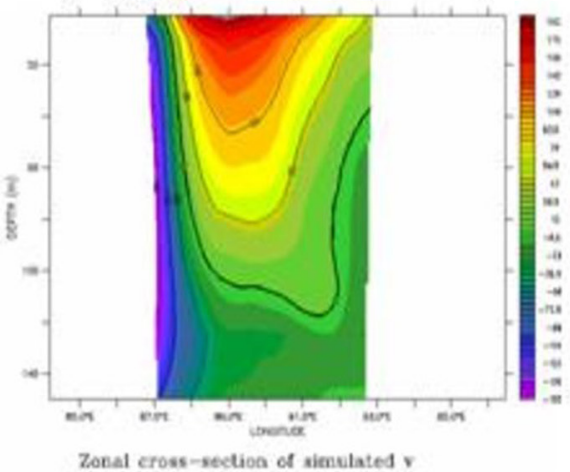

Figure 11. Zonal cross-section of modeled v current ( $\mathrm{cm} / \mathrm{s}$ ) along transects II (upper panel) and I (lower panel). 


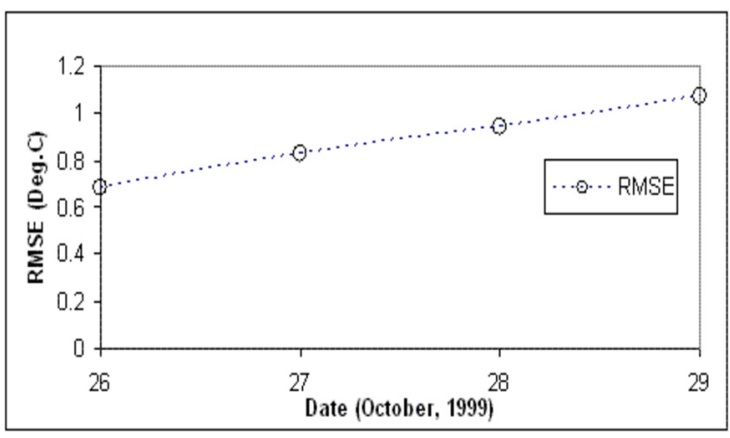

Figure 12. Root Mean Square error between TRMM/TMI SST and modeled SST.

the POM-modeled SST fields for cyclone Ernie (1996). However, the RMS error in the present study is on a par with the RMS error calculated for Ernie (1996) in SCS.

\section{CONCLUSIONS}

This study addresses the SST cooling, vertical thermal characteristics and surface/subsurface circulation responses due to the Orissa super cyclone, 1999 in the $\mathrm{BoB}$, based on the POM model simulated results. The model was forced with the wind model generated wind fields superimposed with satellite derived and reanalysis (QSCAT/NCEP) blended ocean winds. Many expected features of the ocean's response were produced by the model. Thermal response due to the cyclone is well simulated by the model. Analyses of the results show significant sea surface temperature (SST) cooling in the wake of the cyclone on different days of its passage. The higher SST cooling could be attributed to the combined effect of the relatively slower movement of the cyclone and the mixing due to cyclonic wind stress. However, not only is a rightward bias in SST cooling to be observed in this study but also the less commonly observed response of a leftward bias in SST cooling. The SST cooling depicted a stronger response in the model compared to the Tropical Rainfall Measuring Mission (TRMM) Microwave Imager (TMI) filled up SST. It is possible that a misrepresentation of the low salinity surface layer leads to the intense cooling of the surface temperature in the model as compared to that of observations. Vertical thermal response up to the depth of $>200 \mathrm{~m}$ and the upsloping of the thermocline due to upwelled cooler water through surface divergence and the Ekman type of transport is well represented in the simulation. Surface cooling and considerable subsurface warming and variations in thickness of MLD are indicated by the model. Highly divergent surface currents in the open oceanic regions that produced the strong upwelling were also reflected. Modeled surface currents show some deviation on comparison with OSCAR surface currents. Important features like the north-south coastal jet are produced by the model during the cyclone as a strong western boundary current, along the east coastal oceanic region of the Indian subcontinent, which OSCAR also reflected. However, in the coastal regions no right asymmetry in current structure could be observed. Model fields depicted the current shear between the mixed layer and the thermocline zone as a reversal current.

Although POM adequately simulated the BoB's response to the Orissa super cyclone, 1999 much more work in modeling on ocean forcing by cyclones is required. 3-D temperature and salinity observations during the passage of the cyclones would improve the initialization of the model and more realistic results could be drawn. At the same time, the coupling of POM with the atmospheric components of the model (which could provide realistic momentum and thermal forcing) would be more useful in predicting and studying the cyclone's genesis, intensification and dissipation processes.

\section{ACKNOWLEDGEMENTS}

We acknowledge our debt to the Ministry of Science and Technology (Science and Engineering Research Council) of the Government of India for the partial research grant (No.SR/FTP/ES-019/2003) under the SERC_FTYS program and to CAS, IIT Delhi for making their research facilities available to us. Our thanks are also due to the Atmospheric and Oceanic Sciences Program of Princeton University, the Geophysical Fluid Dynamics Laboratory of NOAA and to Dynalysis of Princeton for the Princeton Ocean Model (POM). The TRMM TMI data and images were produced by Remote Sensing Systems and supported by NASA's Earth Science Information Partnership (ESIP): a federation of information sites for the Earth Sciences, and by the TRMM science team. QSCAT/NCEP data are produced by the NASA Quikscatterometer team. We would also record our gratitude to NGDC for bathymetry and other data, UCAR for QSCAT/NCEP data, OSCAR for surface current data and PMEL for ferret. The authors are grateful to the reviewer and the editor for their constructive comments for the improvement of the revised manuscript. 


\section{REFERENCES}

ALI, M. M.; SHARMA, R. Estimation of mixed layer depth in the equatorial Indian ocean using Geosat Altimeter data. Mar. Geod., v. 17, n. 1, p. 63-72, 1994.

BEHERA, S. K.; DEO, A. A.; SALVEKAR, P. S. Investigation of mixed layer response to. Bay of Bengal cyclone using a simple ocean model. Meteorol. Atmos. Phys., v. 65, n. 1, p. 77-91, 1998 .

BENDER, M. A.; GINNIS, I.; KURIHARA, Y. Numerical simulations of tropical cyclone-ocean interaction with a highresolution coupled model. J. Geophys. Res., v. 98, n. D12, p. 23245-23263, 1993.

BHAT, G. S. Near-surface variations and surface fluxes over the northern Bay of Bengal during the 1999 Indian summer monsoon. J. Geophys. Res., v. 107, n. D17, p. 4336, 2002.

BLUMBERG, A. F.; MELLOR, G. L. A Description of a ThreeDimensional Coastal Ocean Circulation Model. In: HEAPS NS (Ed.). Three dimensional ocean models. Washington: American Geophysical Union, 1987. p. 1-16.

CARR, L. E. III; ELSBERRY, R. L. Models of Tropical cyclone wind distribution and beta-effect propagation for application to tropical cyclone track forecasting. Mon. Weather Rev., v. 125, p. 3190-3209, 1997.

CHIN, T. M.; MILLIFF, R. F.; LARGE, W. G. Basin-scale, highwave number sea surface wind fields from a multiresolution analysis of Scatterometer data. J. Atmos. Oceanic Tech., v. 15, p. 741-763, 1998.

CHINTHALU, G. R.; SEETARAMAYYA, P.; RAVICHANDRAN, M.; MAHAJAN, P. N. Response of the Bay of Bengal to Gopalpur and Paradip super cyclones during 15-31 October 1999. Curr. Sci., v. 81, n. 3, p. 283-291, 2001.

CHU, P. C.; SHIHUA, L.; CHEN, Y. Evaluation of the Princeton Ocean Model using South China Sea Monsoon Experiment (SCSMEX) data. J. Atmos. Oceanic Tech., v. 18, n. 9, p. 1521$1539,2001$.

CHU, P. C.; CHEN, Y.; SHIHUA, L. On Haney-type surface thermal boundary conditions for ocean circulation models. $J$. Phys. Oceanogr., v. 28, p. 890-901, 1988.

CHU, P. C.; VENEZIANO, J. M.; FAN, C. Response of the South China Sea to tropical cyclone Ernie 1996. J. Geophys. Res., v. 105, n. C6, p.13991-14009, 2000.

D'ASARO, E. A. The ocean boundary layer below Hurricane Dennis. J. Phys. Oceanogr., v. 33, n. 3, p. 561-579, 2003.

DA SILVA, A. M.; YOUNG, C. C.; LEVITUS, S. Atlas of surface marine data 1994 volume 3: Anomalies of heat and momentum fluxes, NOAA Atlas NESDIS 8 US Department of commerce. Washington: NOAA, NESDIS, 1994.

DARE, R. A.; MCBRIDE, J. L. Sea surface temperature response to tropical cyclones. Mon. Weather Rev., v. 139, p. 37983808, 2011.

DAS, Y.; MOHANTY, U. C. Simulation on some aspect of airsea interaction parameters over Bay of Bengal (Indian Ocean) using one-dimensional numerical model. Am. J. Mar. Sci., v. 2, n. 1, p. 9-18, 2014.

DAS, Y.; MOHANTY, U. C.; JAIN, I. Development of tropical cyclone wind field for simulation of storm surge/sea surface height using numerical ocean model. Model. Earth Syst. Environ., v. 2, n. 13, p. 1-22, 2016.
DAS, Y.; MOHANTY, U. C.; JAIN, I.; RAO, M. S.; MURTY, A. S. N. Modeling on the aspects of thermal response of Bay of Bengal to Tropical cyclone TC05B 1999 using Princeton Ocean Model (POM): Preliminary results. Am. J. Model. Optim. 2.2, v. 2, n. 2, p. 47-59, 2014.

DEO, A. A.; GANER, D. W.; SALVEKAR, P. S. Simulation of ocean upper layer response to moving Indian Ocean cyclone using Reduced Gravity Ocean Model. Mar. Geol., v. 35, n. 2, p. 121-140, 2012.

DICKEY, T.; FRYE, D.; MCNEIL, J.; MANOV, D.; NELSON, N.; SIGURDSON, D.; JANNASCH, H.; SIEGEL, D.; MICHAELS, T.; JOHNSON, R. Upper-ocean temperature response to Hurricane Felix as measured by the Bermuda Testbed Mooring. Mon. Weather Rev., v. 126, p. 1195-1201, 1998.

ELSBERRY, R. L.; FRAIM, T. S.; TRAPNELL JR, R. N. A mixed layer model of the oceanic thermal response to hurricanes. $J$. Geophys. Res., v. 81, p. 1153-1162, 1976.

EMANUEL, K. A. An air-sea interaction theory for tropical cyclones. Part I: Steady-state maintenance. J. Atmos. Sci., v. 43, n. 6, p. 585-604, 1986.

EMANUEL, K. A. The maximum intensity of hurricanes. $J$. Atmos. Sci., v. 45, n. 7, p. 1143-1155, 1988.

EZER, T. On the seasonal mixed layer simulated by basin-scale ocean model and Mellor-Yamada turbulence scheme. $J$. Geophys. Res., v. 105, n. C7, p. 16843-16855, 2000.

GENTRY, R. C. Modifying the greatest storm on Earth-The Hurricane. Underw. Sci. Technol. J., v. 2, n. 4, p. 204-214, 1970.

GEORGIOU, P. N. Design wind speeds in tropical cyclone prone regions [Doctor of Philosophy Dissertation] University of Western Ontario, 1986. 295 p.

GILLIE, S. T. Statistical characteristics of zonal and meridional wind Stress. J. Atmos. Oceanic Tech., v. 22, n. 9, p.1352$1372,2005$.

GIRISHKUMAR, M. S.; RAVICHANDRAN, M.; HAN, W. Observed intraseasonal thermocline variability in the Bay of Bengal. J. Geophys. Res., v. 118, n. 7, p. 3336-3349, 2013.

GOPALAKRISHNA, V. V.; MURTY, V. S. N.; SARMA, M. S. S.; SASTRY, J. S. Thermal response of upper layers of Bay of Bengal to forcing of a severe cyclonic storm: A case study. Indian J. Mar. Sci., v. 22, n. 1, p. 8-11, 1993.

GREATBATCH, R. J. On the response of the ocean to a moving storm: the nonlinear dynamics. J. Phys. Oceanogr., v. 13, p. 357-367, 1983.

HALTINER, G.; WILLIAMS, R. Numerical weather prediction and dynamical meteorology. New York: Wiley, 1980. 477 p.

HANEY, R. L. Surface Thermal boundary conditions for ocean circulation models. J. Phys. Oceanogr., v. 1, n. 4, p. 241-248, 1971.

HANEY, R. L. On the pressure gradient force over steep topography in sigma coordinate ocean models. J. Phys. Oceanogr., v. 21, n. 4, p. 610-619, 1991.

HOLLAND, G. J. An analytic model of the wind and pressure profiles in hurricanes. Mon. Weather Rev., v. 108, p. 1212$1218,1980$.

HONG, C. H.; MASUDA, A.; YOON, J. H. Upper ocean responses to typhoons in the northwestern pacific. Rep. Res. Inst. App. Mech. Kyushu Univ., v. 143, p. 55-62, 2012. 
INDIA METEOROLOGICAL DEPARTMENT. Reports on cyclonic disturbances over north Indian Ocean during 1999. New Delhi: RSMC Tropical cyclones, Report, 2000.

JACOB, S. D.; SHAY, L. K. The role of oceanic mesoscale features on the tropical cyclone-induced mixed layer response: A case study. J. Phys. Oceanogr., v. 33, p. 649-676, 2003.

JACOB, S. D.; SHAY, L. K.; MARIANO, A. J. The 3D oceanic mixed layer response to hurricane Gilbert. J. Phys. Oceanogr., v. 30, p. 1407-1429, 2000.

JAIMES, B.; SHAY, L. K. Enhanced wind driven downscaling flow in warm oceanic eddy features during the intensification of tropical cyclone Issac (2012): Observations and theory. $J$. Phys. Oceanogr., v. 45, n. 6, p. 1669-1689, 2015.

JELESNIANSKI, C. P.; TAYLOR, A. D. A preliminary view of storm surges before and after storm modification. Boulder: Environmental Research Laboratories, Weather Modification Program Office, 1973, 33 p.

JULLIEN, S.; MENKES, C. E.; MARCHESIELLO, P.; JOURDAIN, N. C.; LENGAIGNE, M.; KOCH-LARROUY, A.; LEFÈVRE, J.; VINCENT, E. M.; FAURE, V. Impact of tropical cyclones on the heat budget of the South Pacific Ocean. $J$. Phys. Oceanogr., v. 42, n. 11, p. 1882-1906, 2012.

KALSI, S. R. Orissa super cyclone - A synopsis, Mausam, v. 57, p. 1-20, 2006.

KARA, A. B.; ROCHFORD, P. A.; HURLBURT, H. E. An Optimal definition of ocean mixed layer depth. J. Geophys. Res., v. 105, n. C7, p.16803-16821, 2000.

KARA, A. B.; ROCHFORD, P. A.; HURLBURT, H. E. Mixed layer depth variability over the global ocean. J. Geophys. Res., v. 108, n. 3, p.1-5, 2003a.

KARA, A. B.; WALLCRAFT, A. J.; HURLBURT, H. E. Climatological SST and MLD prediction from a Global Layered Ocean Model with an embedded mixed layer. $J$. Atmos. Oceanic Tech., v. 20, n. 11, p. 1616-1632, 2003 b.

KLEIN, P. High-frequency winds and eddy-resolving models. In: MATHEW, W. H.; IASUMI, H. (Eds.). Ocean modeling in an eddying regime (Geophysical monograph series). Washington: American Geophysical Union, 2008. p. 83-99.

LEIPPER, D. F. Observed ocean conditions and hurricane Hilda 1964. J. Atmos. Sci., v. 24, n. 2, p. 182-196, 1967.

LEVITUS, S.; BOYER, T. P. World ocean atlas 1994 volume 4: Temperature NOAA atlas NESDIS 4 US Department of commerce. Washington, 1994a. 117 p. 1994.

LEVITUS, S.; BURGETT, R.; BOYER, T. P. World Ocean atlas 1994 volume 3: Salinity NOAA atlas, NESDIS 4 US Department of commerce. Washington, 1994b. 99 p.

LEVITUS, S. Climatological atlas of the world ocean. NOAA Prof. Pap. Government Printing Office. Washington, 1982. $173 \mathrm{p}$.

LIANG, J. H.; MCWILLIAMS, J. C.; KURIAN, J.; COLAS, F.; WANG, P.; UCHIYAM, Y. Mesoscale variability in the northeastern tropical Pacific: Forcing mechanisms and eddy properties. J. Geophys. Res., v. 117, n. C7, 2012.

LISAN, Y. U.; O'BRIEN, J. J.; YANG, J. On the remote forcing of the circulation in the Bay of Bengal. J. Geophys. Res., v. 96, n. C11, p. 20449-20454, 1991.

MAEDA, A. On the variation of the vertical thermal structure. $J$. Oceanogr. Soc. Japan, v. 20, n. 6, p. 255-263, 1964.
MAHAPATRA, D. K.; RAO, A. D.; BABU, S. V.; SRINIVAS, C. Influence of coastline on upper oceans response to the tropical cyclone. Geophys. Res. Lett., v. 34, n. 17, p. 1-3, 2007.

MANEESHA, K.; MURTY, V. S. N.; RAVICHANDRAN, M.; LEE, T.; YU, W.; MCPHADEN, M. J. Upper ocean variability in the Bay of Bengal during the tropical cyclones Nargis and Laila. Prog. Oceanogr., v. 106, p. 49-61, 2012.

MAO, Q.; CHANG, S. W.; PFEFFER, R. L. Influence of largescale initial oceanic mixed layer depth on tropical cyclones. Mon. Weather Rev., v. 128, p. 4058-4070, 2000.

MCBRIDE, J. L. Tropical cyclone formation. In: ELSBERRY, R. L. (Ed.). Global perspectives on tropical cyclone. Geneva: World Meteorological Organization, 1995. p. 63-105.

MCCREARY, J. P.; KUNDU, P. K.; MOLINARI, R. L. A numerical investigation of dynamics, thermodynamics and mixed-layer processes in the Indian Ocean. Prog. Oceanogr., v. 31, n. 3, p.181-244, 1993.

MELLOR, G. L. Users guide for a three-dimensional primitive equation numerical ocean model. Princeton: Princeton University, 2004. 56 p.

MELLOR, G. L.; YAMADA, T. Development of a turbulence closure model for geophysical fluid problems. Rev. Geophys., v. 20 , n. 4 , p. $851-875,1982$.

MILLIFF, R. F.; MORZEL, J. The global distribution of the timeaverage wind stress curl from NSCAT. J. Atmos. Sci., v. 58, n. 2, p. 109-131, 2001

MILLIFF, R. F.; MORZEL, J.; CHELTON, D. B.; FREILICH, M. H. Wind stress curl and wind stress divergence biases from rain effects on QSCAT surface wind retrievals. J. Atmos. Oceanic Tech., v. 21, n. 8, p. 1216-1231, 2004.

MILLIFF, R. F.; LARGE, W. G.; MORZEL, J.; DANABASOGLU, G.; CHIN, T. M. Ocean general circulation model sensitivity to forcing from Scatterometer winds. J. Geophys. Res., v. 104, n. C5, p. 11337-11358, 1999.

MOHANTY, U. C.; MANDAL, M.; RAMAN, S. Simulation of Orissa Super Cyclone (1999) using PSU/NCAR Mesoscale Model. Nat. Hazards, v. 31, n. 2, p. 373-390, 2004.

MOHANTY, U. C.; SAM, N. V.; DAS, S.; SATYANARAYANA, A. N. V. A study on the structure of the convective atmosphere over the Bay of Bengal during BOBMEX-99. J. Earth Syst. Sci., v. 112, n. 2, p. 147-163, 2003.

MOREY, S. L.; BOURASSA, M. A.; DUKHOVSKOY, D. S.; O'BRIEN, J. J. Modeling studies of the upper ocean response to a tropical cyclone. Ocean. Dyn., v. 56, n. 5, p. 594-606, 2006.

NEETU, S.; LENGAIGNE, M.; VINCENT, E. M.; VIALARD, J.; MADEC, G.; SAMSON, G.; RAMESH KUMAR, M. R.; DURAND, F. Influence of upper-ocean stratification on tropical cyclone-induced surface cooling in the Bay of Bengal. J. Geophys. Res., v. 117, n. C12, 2012.

NELSON, N. B. Spatial and temporal extent of sea surface temperature modifications by hurricanes in the Sargasso Sea during the 1995 season. Mon. Weather Rev., v. 126, p. 1364$1368,1998$.

OEY, L. Y.; EZER, T.; LEE, H. C. Loop Current, rings and related circulation in the Gulf of Mexico: A review of numerical models and future challenges. In: STURGES, W.; FERNANDEZ, A. L. (Eds.). Ocean circulation in the Gulf of Mexico: observations and models, Geophysical Monograph Ser. Washington, 2005. p. 31-56. 
POTEMRA, J. T.; LUTHER, M. E.; O'BRIEN, J. J. The seasonal circulation of the upper ocean in the Bay of Bengal. $J$. Geophys. Res., v. 96, n. C7, p. 12667-12683, 1991.

PREMKUMAR, K.; RAVICHANDRAN, M.; KALSI, S. R.; SENGUPTA, D.; GADGIL, S. First results from a new observational system over the Indian seas. Curr. Sci., v. 78, n. 3, p. 323-330, 2000.

PRICE, J. F. Upper ocean response to a hurricane. J. Phys. Oceanogr., v. 11, p. 153-175, 1981.

RAO, A. D.; DASH, S.; BABU, S. V.; JAIN, I. Numerical modeling of cyclone impact on the ocean - a case study of the Orissa Supper Cyclone. J. Coast. Res., v. 23, n. 5, p. 12451250, 2007.

RAO, A. D.; MADHU, J.; JAIN, I.; RAVICHANDRAM, M. Response of subsurface waters in the eastern Arabian Sea to tropical cyclones. Estuar. Coast. Shelf Sci., v. 89, n. 4, p. $267-$ 278, 2010.

RAO, R. R. Further analysis on the thermal response of the upper Bay of Bengal to the forcing of pre-monsoon cyclonic storm and summer monsoonal onset during MONEX-79. Mausam, v. 38, p. $147-156,1987$.

RAO, Y. R. The Bay of Bengal tropical cyclones. Curr. Sci., v. 82, n. 4, p. 379-381, 2002.

RIEHL, H. Climate and weather in the tropics. New York: Academic Press, 1979, 394 p.

SADHURAM, Y. Record decrease of sea surface temperature following the passage of super cyclone over the Bay of Bengal. Curr. Sci., v. 86, n. 3, p. 383-384, 2004.

SAUNDERS, M. A.; HARRIS, A. R. Statistical evidence links exceptional 1995 Atlantic hurricane season to record sea warming. Geophys. Res. Lett., v. 24, n. 10, p. 1255-1258, 1997.

SCHENKEL, B. A.; HART, R. E. An examination of tropical cyclone position, intensity, and intensity life cycle within atmospheric reanalysis datasets. J. Clim., v. 25, n. 10, p. 3453-3475, 2012.

SEETARAMAYYA, P.; MASTER, A. Observed air-sea interface conditions and a monsoon depression during MONEX-79. Arch. Meteorol. Geoph. Bioclim, Series A, v. 33, n. 1, p. 6167, 1984

SEETARAMAYYA, P.; NAGAR, S.; MULLAN, A. Response of the North Bay of Bengal (Head Bay) to monsoon depression during MONTBLEX-90. Glob. Atmos. Ocean Syst., v. 7, n. 4, p. 325-345, 2001.

SENGUPTA, D.; BHARATH, R. G.; ANITHA, D. S. Cycloneinduced mixing does not cool SST in the post-monsoon North Bay of Bengal. Atmos. Sci. Lett., v. 9, p. 1-6, 2008.

SHAY, L. K.; UHLHORN, E. W. Loop current response to hurricanes Isidore and Lili. Mon. Weather Rev., v. 136, p. 3248-3274, 2008.

SHAY, L. K.; BLACK, P. G.; MARIANO, A. J.; HAWKINS, J. D.; ELSBERRY, R. L. Upper ocean response to hurricane Gilbert. J. Geophys. Res., v. 97, n. C12, p. 20227-20248, 1992.

SHAY, L. K. Oceanic Response to tropical cyclones. In: MUJUMDAR, S. K.; MILLER, E. W.; FORBES, G. S.; SCHMALZ, R. F.; PANAH, A. A. (Eds.). The oceans: physical-chemical dynamics and human impact. Philadelphia: The Pennsylvania Academy of Science, 1994. 497 p.
SHETYE, S. R.; GOUVEIA, A. D.; SHENOI, S. S. C.; SHANKAR, D.; VINAYACHANDRAN, P. N.; SUNDAR, D.; MICHAEL, G. S.; NAMPOTHIRI, G. Hydrography and circulation in the western Bay of Bengal during the northeast monsoon. J. Geophys. Res., v. 101, n. C6, p. 14011-14025, 1996.

SMAGORINSKY, J. General circulation experiments with the primitive equations I: The basic experiment. Mon. Weather Rev., v. 91, n. 3, p. 99-164, 1963.

STRAMMA, L.; CORNILlION, P.; PRICE, J. F. Satellite observation of sea surface cooling by hurricanes. J. Geophys. Res., v. 91, n. C4, p. 5031-5035, 1986.

SUBRAHMANYAM, B.; MURTY, V. S. N.; SHARP, R. J.; O'BRIEN, J. J. Air-sea coupling during the tropical cyclone in the Indian Ocean: A case study using satellite observations. Pure Appl. Geophys., v. 162, n. 8, p. 1643-1672, 2005.

VENEZIANO, J. M. Response of South China Sea to forcing by tropical cyclone Ernie (1996). $\mathrm{PhD}$ (Dissertation) Naval Post Graduate School Monterey, California, 1998. 193 f. http://calhoun.nps.edu/bitstream/handle/10945/8918/ responseofsouthc00vene.pdf?sequence $=3$

VINAYCHANDRAN, P. N.; MURTY, V. S. N.; RAMESHBABU, $\mathrm{V}$. Observations of barrier layer formation in the Bay of Bengal during southwest monsoon. J. Geophys. Res., v. 107, n. C12, p. SRF 19-1-SRF 19-9, 2002.

VINCENT, E. M.; MADEC, G.; LENGAIGNE, M.; KOCHLARROUY, A.; VIALARD, J. Influence of tropical cyclones on sea surface temperature seasonal cycle and ocean heat transport. Clim. Dynam., v. 41, n. 7, p. 2019-2038, 2012a.

VINCENT, E. M.; LENGAIGNE, M.; MADEC, G.; VIALARD, J.; SAMSON, G.; JOURDAIN, N. C.; MENKES, C. E.; JULLIEN, S. Processes setting the characteristics of sea surface cooling induced by tropical cyclones. J. Geophys. Res., v. 117, n. C2, 2012 b.

VINCENT, E. M.; LENGAIGNE, M.; VIALARD, J.; MADEC, G.; JOURDAIN, N. C.; MASSON, S. Assessing the oceanic control on the amplitude of sea surface cooling induced by tropical cyclones. J. Geophys. Res., v. 117, n. C5, 2012c.

VISSA, N. K.; SATYANARAYANA, A. N. V.; KUMAR, B. P. Response of upper ocean and impact of barrier layer on Sidr cyclone induced sea surface cooling. Ocean Sci. J., v. 48, n. 3, p. 279-288, 2013.

WADA, A. The processes of SST cooling by typhoon passage and case study of typhoon Rex with a mixed layer ocean model. Pap. Meteorol. Geophys., v. 52, n. 2, p. 31-66, 2002.

WADA, A. Numerical simulations of sea surface cooling by a mixed layer model during the passage of typhoon Rex. $J$. Oceanogr., v. 61, n. 1, p. 41-57, 2005.

WANG, J. W.; HAN, W.; SRIVER, R. L. Impact of tropical cyclones on the ocean heat budget in the Bay of Bengal during 1999: 1. Model configuration and evaluation. J. Geophys. Res., v. 117, n. C9, 2012a.

WANG, J. W.; HAN, W.; SRIVER, R. L. Impact of tropical cyclones on the ocean heat budget in the Bay of Bengal during 1999: 2. Processes and interpretations. J. Geophys. Res., v. 117, n. C9, 2012 b.

WANG, J. W.; HAN, W. The Bay of Bengal upper-ocean response to tropical cyclone forcing during 1999. J. Geophys. Res., v. 119, p. 98-120, 2014. 
WENTZ, F. J.; GENTEMANN, C.; SMITH, D.; CHELTON, D. Satellite measurements of sea surface temperature through clouds. Science, v. 288, n. 5467, p. 847-850, 2000.

WHITHEE, G. W.; JOHNSON, A. Data report: Buoyobservations during hurricane Eloise (September 19 to October 11, 1975): data report. Washington: US Dep. Commer, 1988, 21 p.

WILlOUGHBY, H. E.; DARLING, R. W. R.; RAHN, M. E. Parametric representation of the primary hurricane vortex Part II: A new family of sectionally continuous profiles. Mon. Weather Rev., v. 134, n. 4, p. 1102-1120, 2006.
WRIGHT, R. Temperature structure across the Kuroshio before and after typhoon Shirley. Tellus, v. 21, n. 3, p. 409-413, 1969.

ZEDLER, S. E.; DICKEY, T. D.; DONEY, S. C.; PRICE, J. F.; YU, X.; MELLOR, G. L. Analysis and simulations of the upper ocean's response to hurricane Felix at the Bermuda Testbed Mooring site: 13-23 August 1995. J. Geophys. Res., v. 107 , n. C12, p. $25-29,2002$.

ZEDLER, S. E. Simulated ocean response to a hurricane Nonlinear processes. J. Phys. Oceanogr., v. 39, n. 10, p. 2618-2634, 2009. 